Synthesis, part of a Special Feature on Telecoupling: A New Frontier for Global Sustainability

\title{
Peruvian anchoveta as a telecoupled fisheries system
}

\author{
Andrew K. Carlson ${ }^{1,2}$, William W. Tavlor $^{1,2}$, Jianguo Liu $^{1,2}$ and Ivan Orlic $^{1}$
}

\begin{abstract}
Fisheries are coupled human and natural systems (CHANS) across distant places, yet fisheries research has generally focused on better understanding either fisheries ecology or human dimensions in a specific place, rather than their interactions over distances. As economic and ideational globalization accelerate, fisheries are becoming more globally connected via movements of fish products and fisheries finances, information, and stakeholders throughout the world. As such, there is a pressing need for systematic approaches to assess these linkages among global fisheries, their effects on ecosystems and food security, and their implications for fisheries science and sustainability. Use of the telecoupling framework is a novel and insightful method to systematically evaluate socioeconomic and environmental interactions among CHANS. We apply the telecoupling framework to the Peruvian anchoveta (Engraulis ringens) fishery, the world's largest single-species commercial fishery and a complex CHANS. The anchoveta fishery has diverse and significant telecouplings, socioeconomic and environmental interactions over distances, with the rest of the world, including fishmeal and fish oil trade, monetary flow, knowledge transfer, and movement of people. The use of the telecoupling framework reveals complex fishery dynamics such as feedbacks (e.g., profit maximization causing fishery overcapitalization) and surprises (e.g., stock collapse) resulting from local and long-distance ecological and socioeconomic interactions. The Peruvian anchoveta fishery illustrates how the telecoupling framework can be used to systematically assess the magnitude and diversity of local and distant fisheries interactions and thereby advance knowledge derived from traditional monothematic research approaches. Insights from the telecoupling framework provide a foundation from which to develop sustainable fisheries policy and management strategies across local, national, and international levels in a globalized world.
\end{abstract}

Key Words: anchoveta; environmental interactions; Peru; socioeconomic interactions; telecoupling framework; telecouplings

\section{INTRODUCTION}

Encompassing aquatic organisms, aquatic habitats, and human users, fisheries are social-ecological systems (Wilson 2006, Cinner 2011, Pinsky and Fogarty 2012) and coupled human and natural systems (CHANS; Liu et al. 2016, Carlson et al. 2017). Amid economic and ideational globalization, fisheries are quickly becoming more globally connected (Crona et al. 2015, TapiaLewin et al. 2017) via movements of fish products and fisheries finances, information, and stakeholders (e.g., fishers, fishmeal producers). Globalization has facilitated such connections among faraway fisheries for centuries, yet "distant water" fishing quickened in the mid-twentieth century as the Soviet Union, Japan, Spain, and other nations harvested fish oceans throughout the world (Österblom and Folke 2015). Today, China is the world's largest producer and consumer of finfish and shellfish (Cao et al. 2015), practicing "contagious exploitation" of sea cucumber (Echinodermata, Holothuroidea spp.) imported from 83 countries (Eriksson et al. 2015) and acquiring fishmeal from Peru, Chile, and Russia to support a rapidly growing aquaculture industry (i.e., 5-6\% annual growth, 2000-2012; China Agriculture Press 2013, FAO 2014). Fish promote food security and support commercial, recreational, and subsistence fisheries throughout the world (Taylor et al. 2007), making it important to understand how the quickening pace of globalization is connecting the human and natural components of fisheries in distant locations.

Fisheries globalization can cause unexpected ecological and socioeconomic effects. For example, distant water fishing by the Soviet Union in the Scotian Shelf and the Baltic and Black seas led to overfishing, fisheries regime shifts, and global governance responses for improved management (Österblom and Folke 2015). Globalization can also expose distant water fishing nations to shocks, i.e., fish and monetary losses caused by stock collapses, policy changes, and other relatively unpredictable events (Gephart et al. 2016, 2017). Livelihoods of artisanal and subsistence fishers can be jeopardized when globalization promotes rapid changes in fish abundance and food supply resulting from competitive fish harvest and exportation to international markets (Crona et al. 2015). As pressure on the world's fisheries continues to rise (Cao et al. 2015), there is a pressing need for scientific tools that can be used to evaluate linkages among global fisheries (e.g., trade, monetary exchange), their effects on ecosystems and food security, and their implications for fisheries science and sustainability.

As economic and ideational globalization accelerate, understanding social-ecological dynamics in local and distant systems is likely to be a burgeoning area of fisheries science, both marine (Essington et al. 2017) and freshwater (Hunt et al. 2016). Despite growth in global fisheries research focusing on international connections among fisheries (Cao et al. 2015, Österblom and Folke 2015, Gephart et al. 2016, Tapia-Lewin et al. 2017), there are still knowledge gaps surrounding these linkages, including their magnitude and extent, underlying causes, and ultimate effects. Hence, there is need for a conceptual paradigm for quantifying and understanding interactions among fisheries across local to global levels. The telecoupling framework enables integrative evaluation of the economic, political, social, cultural, and ecological interactions among CHANS over distances (Liu et al. 2013). It has enhanced knowledge and promoted effective science-based policy and management approaches in terrestrial systems, e.g., Wolong Nature Reserve for giant pandas (Ailuropoda melanoleuca; Liu et al. 2015) and certain aquatic systems, e.g., Chinese urban water systems (Deines et al. 2016, Liu et al. 2016, Yang et al. 2016). Thus, the telecoupling framework is a promising tool for studying globalized fisheries

${ }^{1}$ Center for Systems Integration and Sustainability, Department of Fisheries and Wildlife, Michigan State University, Michigan, USA, ${ }^{2}$ Ecology, Evolutionary Biology, and Behavior, Michigan State University, Michigan, USA 
and addressing knowledge gaps regarding the structure, scale, drivers, and consequences of long-distance fisheries interactions (Crona et al. 2016, Gephardt et al. 2017). By enabling systematic assessment of telecouplings, socioeconomic and environmental interactions between human and natural systems over distances (Liu et al. 2013), the telecoupling framework can reveal crucial information for sustainable fisheries policy and management throughout the world.

The goal of this study was to investigate movements of fish products, money, knowledge, and people associated with the Peruvian anchoveta (Engraulis ringens) fishery using the telecoupling framework to inform development of ecologically, socioeconomically sustainable fishery policy and management approaches now and in the future. We focused on Peruvian anchoveta because this species supports the largest single-species fishery in the world, with 6-7 million metric tons (MMT) of fish harvested annually (Orlic 2011, Avadí et al. 2014). To understand the fishery's telecoupled attributes and inform policy and management, we evaluated the fishery from the late 1940s to the present, a period of rapid growth in Peru's anchoveta harvest and thus fishery-related interactions with other nations (i.e., interactions conducive to telecoupling analysis). Moreover, the governance structures underlying current anchoveta policy and management approaches were created during this era (Orlic 2011), making it a logical, opportune time period to begin a telecoupling analysis.

Today, the Peruvian anchoveta fishery is a globally important aquatic CHANS wherein fish products, money, and information are exchanged throughout the world and fishery stakeholders move long distances within and among nations for anchovetarelated activities (Orlic 2011). By applying the telecoupling framework to the Peruvian anchoveta fishery, we hope to systematically understand its complex environmental and socioeconomic components. Such understanding is crucial for sustainable anchoveta management and policy making, which require knowledge of the fishery's human and natural systems and telecoupled flows (e.g., fish products, money, information), particularly the people and organizations whose decisions affect anchoveta and anchoveta-dependent communities throughout the world.

\section{THE TELECOUPLING FRAMEWORK AND APPLICATIONS}

The telecoupling framework is rooted in extant paradigms such as teleconnection, i.e., environmental interactions between natural systems over distances, and globalization, i.e., socioeconomic interactions between human systems over distances (Dreher et al. 2008, Liu et al. 2013). However, it significantly advances these approaches by allowing simultaneous assessment of socioeconomic and environmental interactions among CHANS. As such, the telecoupling framework provides a way to evaluate fundamental questions (i.e., who, what, when, where, why, and how?) regarding movements of fish products and fisheries finances, information, and stakeholders among CHANS. These movements are termed flows, which are produced by one or more causes (e.g., economic, political, social, cultural, ecological) and facilitated by agents (e.g., individuals, organizations, governments) with resultant effects (Liu et al. 2013). An individual telecoupling involves one or more sending systems, those from which knowledge and materials flow, and receiving systems, those to which knowledge and materials flow (Liu et al. 2013). Spillover systems are those that affect, or are affected by, local, regional, or international interactions between sending and receiving systems (Liu et al. 2013). For instance, when two countries (A and B) harvest fish from the same stock, and country A exports fish to a third country $\mathrm{C}$ while country B does not, country B becomes a spillover system whose fish landings may be affected by fish trade between countries A and C.

Some telecoupling research is data intensive, i.e., involves analysis of data collected by authors (Liu et al. 2015, Sun et al. 2017), whereas other telecoupling research entails synthesis of peerreviewed literature to comprehensively understand relationships among systems, flows, agents, causes, and effects that have historically been studied in isolation, i.e., not using the telecoupling framework (Fang et al. 2016, Hulina et al. 2017). This study is in the latter category. We collaboratively identified telecouplings in the Peruvian anchoveta fishery, and we used primary literature to explain elements of the telecoupling framework relative to each anchoveta telecoupling (sensu Deines et al. 2016, Yang et al. 2016). That is, we examined relevant studies that focused on specific telecoupling components (i.e., systems, flows, agents, causes, effects) and applied the telecoupling framework to link them in the context of sustainable anchoveta policy and management. The present study expanded and advanced thesis research (Orlic 2011) completed by a Peruvian anchoveta expert with personal experience in the fishery and extensive knowledge of government and industry data sources related to it (e.g., IMARPE 1970, IFFO 2009). These information sources and associated peer-reviewed literature were the datadriven knowledge base for our investigation of Peruvian anchoveta telecouplings.

\section{THE PERUVIAN ANCHOVETA FISHERY AS A TELECOUPLED SYSTEM}

The Peruvian anchoveta fishery is located in the Pacific Ocean's Northern Humboldt Current System (NHCS) off the coast of Peru and Chile, in which coastal upwelling transports nutrientrich water into the photic zone, increasing phytoplankton growth (Barber and Chavez 1983) and anchoveta production (Cury et al. 2000). However, relatively warm (El Niño) or cool (La Niña) phases of the Pacific Decadal Oscillation (PDO) change ecosystem productivity. During the El Niño phase, westerly winds move warm surface waters toward Peru, deepening the thermocline and preventing upwelling of nutrient-rich cold water. These conditions reduce phytoplankton abundance and thus anchoveta production, opening a niche for sardine (Sardinops sagax sagax; Bertrand et al. 2004). In contrast, a La Niña upwelling magnifies nutrient flux, increasing anchoveta production and decreasing sardine production (Bakun and Broad 2003, Bakun 2005). Thus, climatic conditions directly regulate the biological production of anchoveta and ultimately the magnitude and timing of fish harvest by nations such as Peru, setting the environmental conditions in which telecouplings occur (Fig. 1).

Anchoveta are primarily processed into fishmeal and fish oil (FMFO) and distributed internationally as feed ingredients for animal agriculture and aquaculture, which are growing industries throughout the world (Smith et al. 2010). A fleet of 1200 Peruvian ships, including 608 steel industrial and 592 wooden vessels, 
Fig. 1. Telecouplings among sending, receiving, and spillover systems in the Peruvian anchoveta fishery. Arrows denote flows among systems, each of which have natural and human components. Peru is the sending system for fishmeal, fish oil, people (e.g., commercial fishers, students), and publications delivered to receiving systems such as China and Germany. Peru is the receiving systems for money, knowledge, and "distant water" fishers from other countries. The United States, Chile, China, and Germany are examples of spillover systems, nations that affect, or are affected by, flows involving sending and receiving systems.
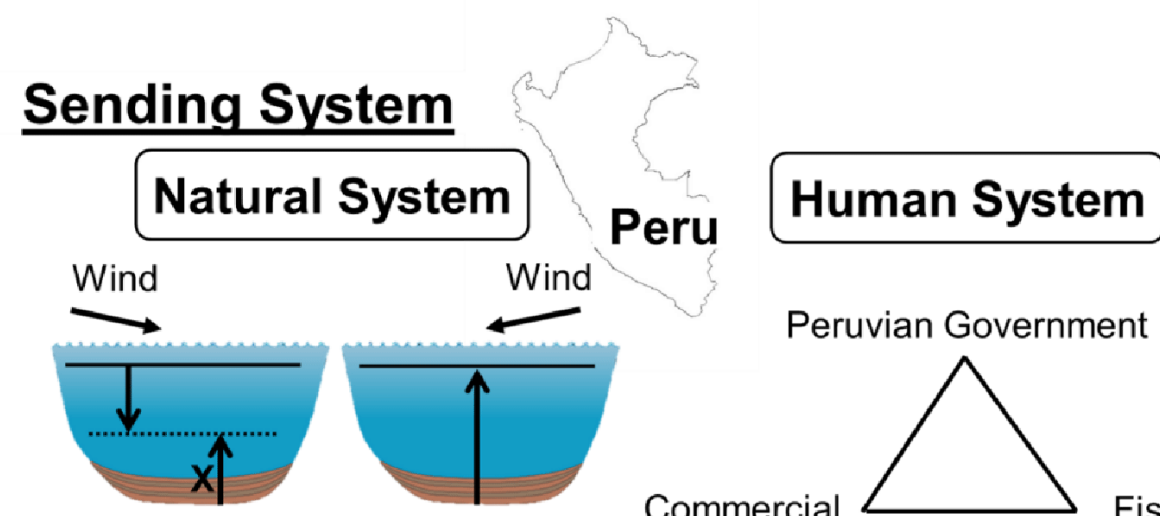

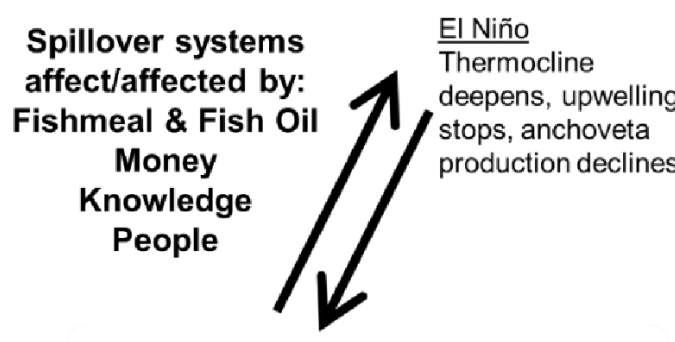

Spillover System

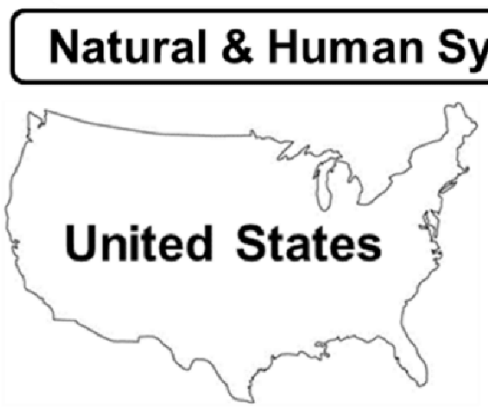

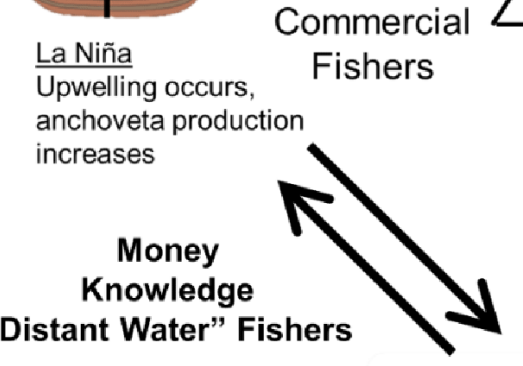

Peruvian Government

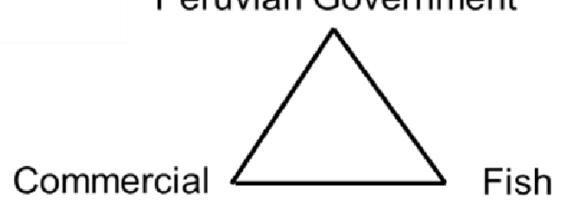

Processors
Fishmeal

Fish Oil

People

Publications

\section{"Distant Water" Fishers}

Receiving System

\section{Natural \& Human Systems}
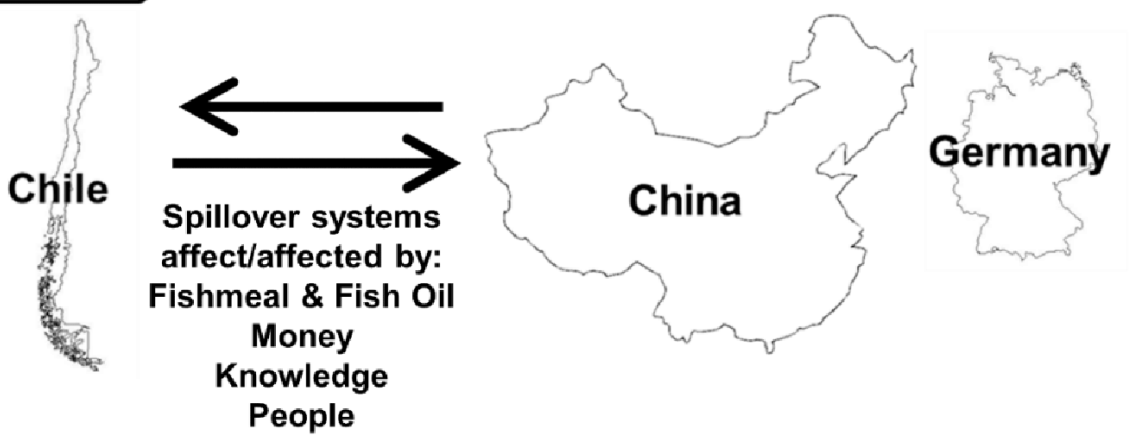

harvests 6-7 MMT of anchoveta every year (Orlic 2011, Avadí et al. 2014). Anchoveta are then transported to Peru's production plants ( $\mathrm{n}=140$; Orlic 2011) in the coastal cities of Chimbote and Pisco, which process over 9000 metric tons of fish per hour and employ 47,000 workers (IFFO 2009, Christensen et al. 2014). Although anchoveta are important to small-scale Peruvian fishers that sell them for direct human consumption (DHC), only two percent of landings are allocated for this purpose (Fréon et al. 2014). In contrast, Peruvian anchoveta support approximately 50 percent of global fishmeal production and 33 percent of global fish oil production, making Peru the largest exporter of FMFO worldwide (Avadí et al. 2014). In turn, global trade of FMFO causes movement of money, information, and people. As such, the anchoveta fishery has four prominent telecouplings: FMFO trade, monetary flow, knowledge transfer, and movement of people.

\section{Systems}

Systems (i.e., sending, receiving, and spillover) are CHANS, integrated units in which humans and nature interact (Liu et al. $2007 a, b$ ). In the FMFO telecoupling, Peru is the sending system, whereas receiving systems are nations that import FMFO, including China, the United States, Germany, Spain, Norway, and Denmark (Table 1, Fig. 1; Orlic 2011, Avadí et al. 2014, Fréon 
Table 1. Summary of systems, flows, agents, causes, and effects associated with telecouplings in the Peruvian anchoveta fishery. FMFO $=$ fishmeal and fish oil.

\begin{tabular}{ll}
\hline \hline Components of the telecoupling framework \\
\hline $\begin{array}{l}\text { Systems } \\
\text { (units in which humans and } \\
\text { nature interact) }\end{array}$ & $\begin{array}{l}\text { Sending } \\
\text { (origins/sources/donors) }\end{array}$ \\
& $\begin{array}{l}\text { Receiving } \\
\text { (destinations/recipients) }\end{array}$ \\
& $\begin{array}{l}\text { Spillover } \\
\text { (systems that affect/are affected by sending- } \\
\text { receiving system interactions) }\end{array}$
\end{tabular}

Flows

(movements of material, information, people, etc., between systems)

\section{Agents}

(autonomous decision-making entites that directly or indirectly facilitate or hinder telecouplings)

\section{Causes}

(factors that influence emergence or dynamics of telecouplings)

$\begin{array}{ll} & \text { Economic } \\ & \text { Political } \\ & \begin{array}{l}\text { Technological } \\ \text { Cultural/human }\end{array} \\ \begin{array}{ll}\text { Effects } \\ \text { (impacts or consequences of }\end{array} & \text { Environmental } \\ \text { telecouplings) } & \text { Socioeconomic } \\ & \text { Before collapse } \\ & \text { After collapse }\end{array}$

Environmental
Examples related to Peruvian anchoveta

Peru (FMFO); China, Denmark, Germany, Norway, Peru, Spain, United

States (money); Peru (knowledge); Peru, Soviet Union (people); Galdorisi and Kaufman (2001), Orlic (2011), Avadí et al. (2014), Fréon et al. (2014)

China, Denmark, Germany, Norway, Spain, United States (FMFO);

Peru (money, knowledge); Peru (people); Galdorisi and Kaufman (2001), Orlic (2011), Avadí et al. (2014), Fréon et al. (2014)

Chile, United States (FMFO); aquaculture and animal agriculture

markets, global wheat market, Northern Humboldt Current System (money); Chile (knowledge); countries Peruvian travelers visit, economies they support (people); Glantz (1979), Barber and Chavez (1983), Orlic (2011), Fréon et al. (2014)

FMFO; money; knowledge (e.g., fishing vessel design, fish harvesting and processing, fishery sustainability strategies, military development strategies); people (e.g., Peruvian and foreign fishers, Peruvian students); Roemer (1970), Berrios and Blasier (1991), Orlic (2011), Fréon et al. (2014), Österblom and Folke (2015)

Fishing companies and commercial fishers (Peruvian); subsistence fishers (Peruvian); governments and political leaders (Peruvian, foreign); "distant water" fishers (foreign); foreign producers (FMFO, aquaculture, animal agriculture); World Bank, United Nations FAO, Inter-American Development Bank; news media outlets, academic journals, book publishers; Glantz (1979), Lemay (1998), Gréboval and Munro (1999), Aguilar Ibarra et al. (2000), McPhaden (2003), Orlic (2011), Österblom and Folke (2015) Climate (Pacific Decadal Oscillation, El Niño, La Niña), anchovetasardine dynamics; Barber and Chavez (1983), Cury et al. (2000), Norton and Mason (2005)

Demand for aquaculture/animal agriculture feed, fish oil; Orlic (2011), Avadí et al. (2014)

Profit-seeking mentality; desire to occupy South America (Soviet Union); Berrios and Blasier (1991), Aguilar Ibarra et al. (2000), Orlic (2011), Österblom and Folke (2015)

Improved fishing and fish processing technology; Orlic (2011)

Protein preference (chicken over anchoveta), desire to feed people; Orlic (2011), Fréon et al. (2014)

Stock collapse (1972); Gréboval and Munro (1999), Bertrand et al. (2004), Orlic (2011)

Revenue, fishery development, employment, coastal development; Aguilar Ibarra et al. (2000), Orlic (2011)

Debt, inflation, unemployment, malnutrition, poverty, decreased wheat demand (United States), wheat scarcity (spillover), international maritime law, paradigms of sustainability, corporate responsibility; Borlaug (1973), Glantz (1979), McPhaden (2003), Orlic (2011) et al. 2014). Spillover systems include those that influence, or are affected by, FMFO trade (Liu et al. 2013). For instance, Peru's historical profit seeking and overcapitalization, wherein fishing vessels and processing plants became unsustainably abundant relative to anchoveta biomass production (Gréboval and Munro 1999), initially increased anchoveta harvest and trade in Peru. This magnified competition between Peru and Chile for finite anchoveta stocks, making Chile a spillover system relative to the Peruvian fishery (Table 1, Fig. 1; Orlic 2011). In addition, after a La Niña phase of the PDO caused a decline in the California sardine (Sardinops sagax caerulea) fishery in the 1940s (Norton and Mason 2005), Peru imported fish processing equipment from the United States, a spillover system that affected the interaction between Peru and anchoveta-importing nations by enabling Peru to export more fish (Table 1; Orlic 2011).

In the fishery finances telecoupling, sending systems are nations that purchase anchoveta-based FMFO from Peru (receiving system) to enhance their food security and socioeconomic wellbeing. These countries include China, Denmark, Germany, Norway, Spain, and the United States (Table 1, Fig. 1; Orlic 2011, Avadí et al. 2014, Fréon et al. 2014). Peru was a sending system when the anchoveta fishery was being established because the Peruvian government purchased infrastructure for fishery 
development, including fish harvesting equipment and processing facilities (Table 1; Orlic 2011). Spillover systems include those that benefit from FMFO acquired by receiving systems, e.g., aquaculture and animal agriculture markets, (Fréon et al. 2014) and those that influence FMFO exports from Peru, e.g., global wheat market, NHCS, (Glantz 1979, Barber and Chavez 1983), or anchoveta payments from sending systems, e.g., Chilean government (Orlic 2011).

In the knowledge transfer telecoupling, historical sending systems were nations such as the United States that delivered fishery information (e.g., harvest techniques, management procedures) to Peru, the receiving system (Table 1, Fig. 1; Orlic 2011). Now, as a global leader in fisheries sustainability (Mondoux et al. 2008), Peru is the sending system for knowledge received by countries seeking to practice sustainable fisheries management. Spillover systems include those, such as Chile, in which people have acquired information (e.g., fish processing techniques, sustainability strategies) from exchanges between sending and receiving systems (Fig. 1; Orlic 2011).

In the human movement telecoupling, sending systems are those from which fisheries stakeholders (e.g., fishers, FMFO producers, politicians) move to Peru, the receiving system (Orlic 2011). For instance, historical distant water fishing nations, such as the Soviet Union (Galdorisi and Kaufman 2001), were sending systems (Table 1, Fig. 1). Peru also acted as a sending system in the 1960s and 1970s when fishers traveled internationally to learn fishing technologies and integrate this knowledge into Peruvian fisheries to improve anchoveta harvest and processing (Orlic 2011). Receiving systems include nations where Peruvian fishers traveled and continue to travel today (Orlic 2011). Spillover systems include countries people visit and economies they make purchases in traveling to and from Peru (Orlic 2011, Liu et al. 2013).

\section{Flows}

Flows are movements of fish products and fisheries finances, information, and stakeholders among CHANS. In the FMFO telecoupling, major flows are movements of FMFO and associated exchange of money and ideas (e.g., historical profitfocused fishery management) throughout the world (Table 1, Fig. 1; Orlic 2011). Peru annually produces 1.3-1.8 MMT of fishmeal and 250,000 metric tons of fish oil worth approximately $\$ 2$ billion U.S. dollars (IFFO 2009, FAO 2010). The vast majority of anchoveta (98\%) is exported for indirect human consumption as FMFO, making Peru the largest anchoveta exporter worldwide. The largest importers of Peruvian anchoveta are China (41-53\% of imports), Germany (12-16\%), Japan (10-13\%), and Taiwan (3-4\%; FAO 2010, Orlic 2011). Anchoveta used for DHC (2\%) are processed into canned $(1.6 \%)$ and frozen $(0.2 \%)$ food products for domestic use and cured anchoveta $(0.2 \%)$ for exportation (Fréon et al. 2014). Although FMFO trade was historically driven by profit seeking and caused fishery overcapitalization, international information flow has since fostered sustainable fisheries management in Peru (Mondoux et al. 2008).

In the fishery finances telecoupling, the principal flow is movement of money from sending to receiving systems, driven by demand for food security and socioeconomic well-being (Table 1, Fig. 1; Orlic 2011). For example, during the 1960s and the 1970s, money from international organizations, such as the World Bank and the United Nations Food and Agriculture Organization
(FAO), flowed into Peru to fund fishery infrastructure, including fishing vessels and fish processing facilities (Lemay 1998). Today, money flows into Peru from sending systems in exchange for FMFO exported to receiving systems (Orlic 2011).

In the knowledge transfer telecoupling, flows include anchoveta harvest/processing methods and fishery management approaches, sustainability strategies, and other forms of knowledge (Table 1, Fig. 1; Orlic 2011). For example, development of the Peruvian anchoveta fishery was catalyzed by flows of information regarding fish harvesting and processing from distant nations, including the United States (Roemer 1970). In the 1960s and 1970s, Peruvian fishing companies acquired knowledge about fishing technologies (e.g., advanced netting, refrigeration) from other countries and implemented these practices in Peru (Orlic 2011), which increased anchoveta harvest and trade (Paulik 1981). Moreover, knowledge flow from the United States caused Peru and Chile to establish exclusive economic zones (EEZs) within 200 miles of their ocean shores in 1947 (Garcia-Amador 1974, Paulik 1981), thereby protecting the integrity of their stocks and of the benefits provided by these fish to national identity and socioeconomic well-being (Orlic 2011). Costa Rica, El Salvador, Honduras, and 10 Arab states and emirates followed suit from 1948-1951 by establishing EEZs to protect coastal fishing and other natural resource rights (e.g., oil, gas, mineral) from exploitation by distant water fishers (Cushman 2013). This demonstrates how fisheries-related knowledge can flow among nations over long distances and ultimately change natural resource policy.

In the human movement telecoupling, the physical relocation of fisheries stakeholders is the principal flow (Table 1, Fig. 1). For example, when the Soviet Union formed a partnership with Peru in the late 1960 s to establish a diplomatic and military presence in South America, 1400 Peruvian students received fellowships to attend universities in the Soviet Union and allied eastern European countries (Table 1; Berrios and Blasier 1991). In return, Peru constructed the Paita complex for docking and servicing of 220 Soviet fishing vessels and facilitated the flow of more than 35,000 Soviet fishers to Peru (Table 1, Fig. 1), along with Soviet military advisors $(n=125)$ and equipment $(250$ tanks, 36 fighter bombers, 16 planes, and 7 helicopters; Berrios and Blasier 1991, Österblom and Folke 2015). Movements of Peruvian fishers traveling to foreign nations to learn fishing methods in the 1960s and 1970s (Orlic 2011) also contributed to the human movement telecoupling. Today, the Peruvian anchoveta fishery employs more than 17,000 commercial fishers, 47,000 fish processors, and 81,500 restaurant workers (Christensen et al. 2014), many of whom travel within Peru and/or internationally (Orlic 2011) and thereby promote the human movement telecoupling.

\section{Agents}

Agents are the individuals, organizations, governments, and other entities that influence flows between sending and receiving systems. In the FMFO trade telecoupling, the Peruvian government, commercial fishers, and fish processors are the principal agents because they make decisions and perform actions (e.g., fish capture, processing) that facilitate international exchange of FMFO (Table 1; Orlic 2011). For instance, recognizing the potential economic value of the anchoveta fishery for export-driven revenue, historical Peruvian political leaders 
maximized short-term profits from the fishery (Glantz 1979, Aguilar Ibarra et al. 2000). Juan Francisco Velasco Alvarado seized the Peruvian government in 1968 and increased state control of the anchoveta fishery to promote national economic growth (Orlic 2011). To maximize profits, Alvarado set an anchoveta harvest quota of 9.5 MMT from 1967 to 1968 and increased it to 12.3 MMT from 1968 to 1969 to increase its economic return (IMARPE 1970). Anchoveta harvest increased dramatically as commercial fishing operations expanded, which caused fishery overcapitalization (Gréboval and Munro 1999).

Outside Peru, FMFO producers and governments are the major agents of FMFO trade in receiving systems because they purchase FMFO and provide these products to recipient industries, e.g., aquaculture or animal agriculture (Table 1; McPhaden 2003). For instance, fish oil producers in Europe affect FMFO exports in Peru by only purchasing products that meet high sanitation standards, which motivates Peruvian fishing companies to ensure they produce high-quality FMFO (IFFO 2009). In spillover systems, commercial fisheries and fishing companies serve as agents because they are affected by changes in anchoveta harvest and trade in the sending system (Table 1; Orlic 2011). Moreover, the World Bank and the FAO were historical agents of FMFO trade in spillover systems because they provided monetary resources for fishery establishment and growth (Table 1; Orlic 2011).

In the fishery finances telecoupling, governments and FMFO producers are the principal agents in sending systems because they make decisions regarding FMFO imports (Table 1; Orlic 2011). However, in receiving systems such as Peru, commercial fishers, fishing companies, and political leaders are the major agents of monetary flow (Orlic 2011). For example, as the Peruvian anchoveta fishery developed during the 1960s and the 1970s, Peruvian commercial fishers, fishing companies, and political leaders were the agents that caused financial flows to establish fishery infrastructure and enhance food security and socioeconomic well-being (Table 1; Gréboval and Munro 1999). In spillover systems, agents of financial flows include aquaculture and animal agriculture producers, political leaders, and others who are affected by monetary exchanges between sending and receiving systems (Table 1; Orlic 2011).

In the knowledge transfer telecoupling, agents in sending systems include commercial fishers, fishing companies, and political leaders who provide knowledge about the fisheries they represent (Table 1; Orlic 2011). For example, Peruvian fishing companies are agents of knowledge transfer in Peru because they supply information about the anchoveta fishery (e.g., fish harvest and processing, fishery sustainability) to receiving systems. In receiving systems, the main agents are the news media outlets, editors and publishers of academic journals and books, and website developers that obtain knowledge from Peru and disseminate it to the scientific and lay audiences that serve as agents in spillover systems (Table 1; Orlic 2011).

In the human movement telecoupling, Peruvian fishing companies and political leaders are the primary agents who cause fishers to move between Peru and receiving systems to learn fishing technologies (Table 1; Orlic 2011). Similarly, governments and fishing companies were the principal agents that caused thousands of distant water fishers to move to Peru from the Soviet
Union, Japan, Spain, and other sending systems in the midtwentieth century (Table 1). Moreover, the Soviet Union was the agent that caused 125 military advisors to travel to Peru and 1400 Peruvian students to move to the Soviet Union and allied eastern European countries (Berrios and Blasier 1991, Galdorisi and Kaufman 2001, Österblom and Folke 2015). Agents in spillover systems include the people travelers interact with as they move to and from Peru (Orlic 2011).

\section{Causes}

Causes are the reasons (e.g., economic, political, social, cultural, ecological) explaining why telecouplings occur. In the FMFO trade telecoupling, climate is a cause of anchoveta production, harvest, and trade (Table 1; Barber and Chavez 1983, Cury et al. 2000). Historically, a political cause of FMFO trade was the desire of the Peruvian government to use its abundant fisheries resources to promote monetary flow and economic growth in Peru (Aguilar Ibarra et al. 2000, Orlic 2011). Although a profit-seeking mentality and unsustainable fishery regulations initiated overcapitalization and overharvest (Gréboval and Munro 1999), the prospect of financial gains generated from anchoveta stocks continues to sustain the fishery and its global importance (Table 1; Glantz 1979). Other causes of FMFO trade are economic, i.e., increasing international demand for feed (e.g., aquaculture, animal agriculture) and fish oil (Avadí et al. 2014, Fréon et al. 2014), and humanitarian, i.e., the desire to feed growing human populations throughout the world (Orlic 2011).

In the fishery finances telecoupling, demand for FMFO and associated food and revenue from aquaculture and animal agriculture production are the principal causes of financial flows from sending systems to Peru (Table 1; Avadí et al. 2014, Fréon et al. 2014). For example, sending systems participate in the international FMFO market because they receive income and profits from the anchoveta-based products they sell (Orlic 2011). In nations that import cured anchoveta for DHC, a humanitarian cause for the monetary flow is the desire to feed people, which supplements economic reasons for importing anchoveta products (Table 1; Orlic 2011). Historically, the need to develop fishery infrastructure to improve food security and socioeconomic wellbeing was the cause for financial flows from Peru to receiving systems (Lemay 1998).

In the knowledge transfer telecoupling, several factors are responsible for flows of information about the Peruvian anchoveta fishery. For instance, fishing companies and political leaders established the fishery under the premise that the sheer abundance of Peruvian anchoveta would provide enhanced income, financial and food security, and national identity (Table 1; Aguilar Ibarra et al. 2000, Orlic 2011). As knowledge about anchoveta harvest and processing spread and infrastructure expanded, a profit-seeking mentality was a major cause of continued knowledge transfer and fishery development (Table 1; Orlic 2011). Overcapitalization and declining profits (economic causes) and eventual stock collapse in 1972 (an ecological cause) prompted Peruvian political leaders and fisheries research organizations to recognize the importance of sustainable fishery management (Gréboval and Munro 1999, Mondoux et al. 2008).

In the human movement telecoupling, a variety of factors cause fisheries stakeholders to move to and from Peru. For example, technological and economic causes for sending Peruvian fishers 
Fig. 2. Effects of the 1972 anchoveta stock collapse as inferred using the telecoupling framework. Events occur in numerical order: (1) stock collapse; (2) effects on soybean and wheat production in the United States; (3) effects on wheat exports to the Soviet Union, China, Egypt, and Indonesia. The stock collapse decreased flows of anchoveta from Peru (i.e., sending system) to the United States (i.e., receiving system; Orlic 2011). This caused the United States to plant less wheat and more soybeans to increase production of soybean-based poultry feeds (McPhaden 2003). In turn, the United States exported less wheat, causing shortages in wheat-importing nations (i.e., spillover systems) and intensifying global wheat scarcity (Glantz 1979). Egypt and Indonesia experienced harmful feedbacks (denoted by dotted arrows) wherein resource-limited domestic wheat production was exacerbated by impaired flows of wheat and fertilizer from the United States due to a shortage of ocean freighters (Orlic 2011).

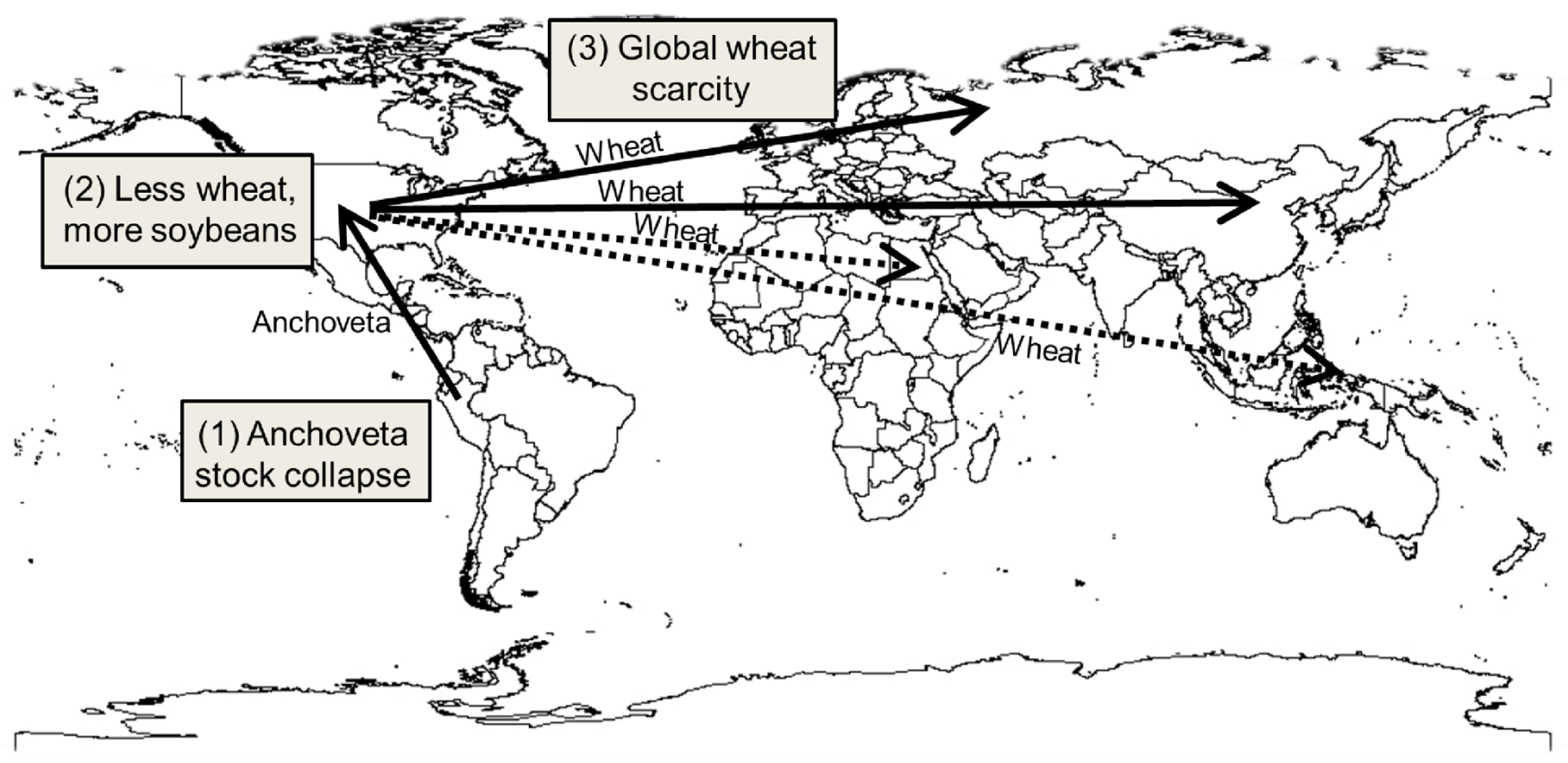

to other countries were the desire of fishing companies to learn new fishing strategies and increase revenue from anchoveta harvest (Table 1; Orlic 2011). In addition, diplomatic and political causes for movement of more than 35,000 distant water fishers and 125 military advisors included the Soviet Union's desire to establish a foothold in Peru and harvest abundant anchoveta stocks (Berrios and Blasier 1991, Galdorisi and Kaufman 2001, Österblom and Folke 2015).

\section{Effects}

Effects are socioeconomic and environmental impacts of telecouplings. In the FMFO trade telecoupling, Peru's participation in international FMFO markets in the 1960 s caused a series of effects: economic growth, employment, coastal development, and accelerated anchoveta harvest and trade (Table 1; Orlic 2011). However, subsequent effects, both economic (overcapitalization) and ecological (stock collapse; Gréboval and Munro 1999, Bertrand et al. 2004), were harmful for Peru and receiving and spillover systems that had come to rely on consistent supplies of anchoveta FMFO and associated revenue (Orlic 2011). For example, the collapse decreased anchoveta harvest in Peru from > 11 MMT to < 2 MMT and reduced FMFO supply for international trade, causing a shortage in receiving systems such as the United States (Orlic 2011). With less FMFO for producing animal feeds, the United States changed its agricultural practices and planted less wheat and more soybeans to increase production of soybean-based feeds for animal agriculture (Fig. 2; McPhaden 2003). This shift caused wheat prices to soar from US\$55 per ton on July 1, 1972 to $\$ 100$ per ton on December 31, 1972 (Borlaug 1973). In turn, the United States exported less wheat, causing shortages in wheat-importing nations (e.g., Soviet Union, China, Indonesia, Egypt) and intensifying global wheat scarcity and food insecurity (Fig. 2; Glantz 1979). Forced to import wheat from international markets, the Soviet Union, China, Indonesia, and Egypt became spillover systems relative to the Peruvian anchoveta fishery (Table 1, Fig. 2; Borlaug 1973). In the aftermath of the stock collapse, Peruvian political leaders and fisheries research organizations (e.g., Instituto del Mar del Peru) recognized that sole focus on profit maximization from FMFO trade was not a sustainable long-term approach for anchoveta management (Orlic 2011).

In addition, FMFO policy decisions in nations outside Peru cause changes in flows of knowledge and materials to and from Peru (Orlic 2011). For example, when European fish oil producers anticipated that the European Union would institute a sanitary regulation for fish oil trade in 2009, fish oil imports swelled before the regulation commenced (Fréon et al. 2014). Ultimately, Peruvian companies invested in fishing technologies such as refrigerated fish holds and recirculating seawater systems to enhance the longevity and safety of harvested anchoveta meat (Orlic 2011). Today, fish oil producers in Norway demand fish oil 
rich in omega-3 fatty acids, which causes Peruvian fishing companies to use processing technologies that increase the omega-3 content of anchoveta-based fish oil (Orlic 2011). These examples illustrate how long-distance socioeconomic interactions cause policy decisions in Europe to cascade back to Peru via knowledge and material flows that incentivize Peruvian fishing companies to export nutritious, sanitary anchoveta FMFO.

In the fishery finances telecoupling, monetary investments from international organizations stimulated development and expansion of the Peruvian anchoveta fishery (Lemay 2008, Orlic 2011). Likewise, throughout the fishery's history, continued financial flows from sending systems to Peru, driven by demand for fish products, food security, and socioeconomic well-being, have ensured the fishery's longevity (Table 1; Orlic 2011). However, a profit-seeking mentality by Peruvian political leaders in the 1960s (Aguilar Ibarra et al. 2000) inhibited the Peruvian government from implementing sustainable fisheries management practices that may have prevented stock collapse and increased economic stability (Aguero and Zuleta 1994, Orlic 2011).

In the knowledge transfer telecoupling, historical effects included increased anchoveta harvest and trade, followed by overcapitalization (Gréboval and Munro 1999), and the emergence of sustainability as a fishery management paradigm (Table 1; Mondoux et al. 2008, Orlic 2011). For example, Peru participated in international conferences in 1987 and 1989 that promoted information exchange regarding sustainable anchoveta management (Orlic 2011). International knowledge transfer also caused Peruvian fishing companies to implement maximum permissible limits for emissions and effluents and offer their employees child education assistance, bonuses and financial incentives, and pensions for early retirement (IFFO 2009). These programs have engendered a sense of corporate responsibility in the Peruvian anchoveta fishery, marking a new era of fishery conservation (Mondoux et al. 2008) and demonstrating the importance of knowledge transfer as a telecoupled fisheries process that impacts social-ecological sustainability (Orlic 2011).

Effects of the human movement telecoupling are diverse and context dependent. For instance, Peruvian fishers historically returned from abroad with knowledge that facilitated use of novel net types (e.g., nylon with high tensile strength) and ship designs with fish refrigeration, recirculating seawater systems, and depth finders (Table 1; Orlic 2011). Continued distant water fishing for anchoveta caused Peru and nearby countries to adopt policies to protect coastal sovereignty (Table 1; Galdorisi and Kaufman 2001). Moreover, Peru's partnership with the Soviet Union during the 1960s and 1970s enabled 1400 Peruvian students to attend international universities and allowed the Soviet Union to gain a diplomatic presence in South America (Berrios and Blasier 1991). Today, the fishery promotes local, regional, and international movement of the 232,000 people it employs directly or indirectly (Christensen et al. 2014) causing the fishery to remain a globally interconnected system with flows of FMFO, money, and knowledge (Orlic 2011).

\section{INTERACTIONS AMONG TELECOUPLED PROCESSES}

Relationships among telecouplings are complex and context dependent. Telecouplings may amplify or inhibit each other, or interact to influence existing telecouplings, or form novel telecouplings (Liu et al. 2013). For instance, international trade of anchoveta FMFO promotes the exchange of money, information, and people in local and distant areas (Lemay 1998, Orlic 2011, Österblom and Folke 2015). In addition, monetary flow promotes FMFO trade and movement of anchoveta stakeholders and their fisheries knowledge (Galdorisi and Kaufman 2001, Orlic 2011). Telecouplings may also offset each other (Liu et al. 2013). For instance, the Peruvian anchoveta fishery illustrates how focusing solely on financial revenue from FMFO trade can inhibit the acquisition of knowledge about biological constraints to fish production and prevent the exchange of information (via international movement of fishers) regarding sustainable fisheries management (Aguilar Ibarra et al. 2000, Orlic 2011).

Telecouplings may interact to influence existing or form novel telecouplings. For instance, fisheries telecouplings (e.g., FMFO trade, monetary exchange) may interact unexpectedly to influence trade and financial telecouplings in other sectors (e.g., agriculture), as demonstrated by the effects of anchoveta on soybeans and wheat (Borlaug 1973, Glantz 1979). Telecouplings may also exhibit complex dynamics (e.g., feedbacks, regime shifts; Liu et al. 2013, Österblom and Folke 2015) that result from distant ecological and socioeconomic interactions. For instance, the desire of Peruvian fishing companies to advance fishing capacity and increase profits (Glantz 1979, Aguilar Ibarra et al. 2000) caused a feedback wherein companies invested progressively more resources to maximize fleet carrying capacities, engendering corporate competition that intensified fishery overcapitalization (Lemay 1998). Moreover, after the unexpected anchoveta collapse caused a reduction in global wheat supply (Borlaug 1973, Glantz 1979), spillover systems to the anchoveta fishery, such as Egypt and Indonesia, experienced a harmful feedback wherein a shortage of ocean freighters impaired flows of wheat and fertilizer from the United States and thereby exacerbated resource-limited domestic wheat production (Fig.2; Orlic 2011).

\section{INSIGHTS OF THE TELECOUPLING FRAMEWORK FOR FISHERIES POLICY AND MANAGEMENT}

The purpose of this study was to use the telecoupling framework to evaluate flows of fish products, money, knowledge, and people in the Peruvian anchoveta fishery and inform development of ecologically, socioeconomically sustainable fishery policy and management approaches now and in the future. We demonstrated how the telecoupling framework enables systematic assessment of the systems, agents, causes, and effects involved in movements of anchoveta products, money, knowledge, and people throughout the world. In turn, evaluation of these telecouplings yields insights for sustainable anchoveta management and policy making. For instance, by illustrating how anchoveta telecouplings caused a biologically productive fishery to become progressively vulnerable to overfishing, overcapacity, stock collapse, and socioeconomic upheaval, the telecoupling framework provides a road map for fishery sustainability. Anchoveta policy and management should not be narrowly focused on individual objectives (e.g., profit maximization), which obscures broader environmental and socioeconomic processes regulating the fishery. Rather, robust policy and management approaches that incorporate telecoupled flows and capitalize on their advantages (e.g., international knowledge transfer promotes fishery sustainability) are needed to protect anchoveta populations and enhance benefits for anchoveta-dependent stakeholders. 
Our results indicate that effects of anchoveta telecouplings are diverse and often complicated, particularly in spillover systems. As such, fisheries professionals should design policy and management strategies that account for spillover effects, particularly those that extend outside the fisheries realm. For example, because anchoveta abundance influences soybean cultivation and wheat availability (Borlaug 1973, Glantz 1979), fisheries and agricultural professionals need to consider the effects of each sector on the other to promote sustainable anchoveta management and international food security. Flow diagrams, mathematical models, and other tools (e.g., agent-based models, social network analysis; Bodin and Prell 2011, Liu et al. 2013) are promising methods for evaluating past and present anchoveta telecouplings. In turn, fisheries professionals can use this information to forecast the systems, flows, agents, causes, and effects associated with future anchoveta telecouplings. Results from this study demonstrate the important contributions of the telecoupling framework for systematically analyzing environmental and socioeconomic fishery interactions and promoting informed anchoveta policy and management.

The utility of the telecoupling framework for fisheries policy and management may extend beyond Peruvian anchoveta. For example, fisheries professional and stakeholders can use the telecoupling framework to identify the values (e.g., social, psychological, aesthetic, ecological, educational) that underlie fisheries systems and track how they change over space and time in relation to ecological conditions (Gelcich et al. 2017). These contributions are important because fisheries professionals and stakeholders must understand the unique values held by citizens and legislators to promote open, transparent communication with these groups and thereby foster public acceptance and legislative support for fisheries management (Knuth 2002). Although the human dimensions of fisheries have been investigated since the 1960s (Fulton and Adelman 2003, Hunt et al. 2013), laying a foundation for recent studies of fisheries as social-ecological systems (Cinner et al. 2012, 2013, Basurto et al. 2013, Castilla et al. 2016, Defeo et al. 2016, Folke et al. 2016), the telecoupling framework has not been widely applied to understand socioeconomic and environmental interactions among fisheries. By operationalizing the process of identifying social-ecological connections and associated management applications in fisheries, the telecoupling framework contributes to the science and management of fisheries as CHANS. Overall, there are numerous opportunities for future researchers to apply the telecoupling framework to investigate the emergence of, spatiotemporal changes in, and interactions among fisheries telecouplings throughout the world.

Using the telecoupling framework demonstrates how systematic assessment of fisheries flows can provide information for policy and management that traditional approaches, i.e., those that only consider socioeconomic or ecological perspectives at a single place, cannot. For instance, after the anchoveta fishery entered a boom period with remarkable fish productivity and public support for fish harvest (Orlic 2011), unexpected consequences (e.g., overcapacity, overfishing, stock collapse) and their interactions can only be explained by examining telecouplings. Similarly, environmental and socioeconomic limitations to anchoveta productivity and eventual improvements in fishery sustainability (Mondoux et al. 2008, Orlic 2011) were telecoupled processes involving social and ecological causes and effects that are only evident using the telecoupling framework. Ultimately, fisheries professionals can use the telecoupling framework to design adaptive policy and management strategies that incorporate knowledge of local and distant socioeconomic and environmental interactions. For example, fisheries professionals and stakeholders can apply the telecoupling framework to trace the origins of fish and fish products (von der Heyden et al. 2014), investigate trade-offs of international fisheries commerce (e.g., revenue versus reduced local food security; Crona et al. 2015), and make informed fish consumption choices (Watson et al. 2016). In turn, fisheries professionals can use this information to develop ecologically, socioeconomically informed fisheries policy and management approaches that promote global, multilevel fisheries governance that accounts for the effects of fish harvest on ecosystems and food security (Crona et al. 2015, Gephart et al. 2016, 2017).

The telecoupling framework offers many contributions that can enhance fisheries science, policy, and management. For instance, the telecoupling framework is a systematic tool for understanding the conditions (e.g., social, political, economic, climatic, ecological) that affect fisheries as CHANS. The telecoupling framework provides an organized method for evaluating the causes and effects of these conditions in a logical manner. This is an important contribution in a fisheries discipline in which uncertainty is common and difficult to overcome (Botsford et al. 1997, Fulton et al. 2011). The telecoupling framework also enables assessment of social-ecological interactions within and among fisheries, a crucial step toward filling knowledge gaps stemming from historical focus on either human or natural components of specific fisheries (Arlinghaus et al. 2013, Hunt et al. 2013). The telecoupling framework also yields innovative insights about fisheries dynamics (e.g., how and why an anchoveta boom led to stock collapse and socioeconomic turmoil, how and why international knowledge transfer fostered fishery sustainability). Such novel information is a critical contribution of the telecoupling framework because it broadens and deepens knowledge provided by traditional research approaches and sets the stage for more integrative science for fishery sustainability. In addition, the telecoupling framework has considerable flexibility (i.e., understanding social-ecological interactions in different fisheries) and applicability (i.e., translating science into policy and management approaches), making it a novel instrument for fisheries science and practice.

In conclusion, the telecoupling framework is an effective tool for investigating long-distance socioeconomic and environmental interactions associated with the globally important Peruvian anchoveta fishery. As a systematic instrument for integrating the diverse social and ecological factors influencing anchoveta and anchoveta-dependent human communities, the telecoupling framework helps clarify the fishery's complex dynamics (e.g., flows, agents, causes, effects, feedbacks). The telecoupling framework is a logical extension to traditional anchoveta research that was either ecologically or socioeconomically focused, providing novel fishery insights (e.g., role of spillover systems, international knowledge exchange) that advance those provided by historical monothematic approaches. In turn, these insights foster robust approaches for informed anchoveta management and policy making. Beyond the Peruvian anchoveta fishery, the 
telecoupling framework is a flexible, widely applicable tool for fisheries science and sustainability. By allowing systematic evaluation of the local to global processes influencing fisheries systems, the telecoupling framework can help promote ecologically and socioeconomically sustainable fisheries policy, management, and governance throughout the world.

Responses to this article can be read online at: http://www.ecologyandsociety.org/issues/responses. php/9923

\section{Acknowledgments:}

We thank the institutions that provided funding for previous telecoupling research on which this manuscript is based: U.S. National Science Foundation, Michigan State University, Michigan AgBioResearch, National Institutes of Health, National Aeronautics and Space Administration, Chinese Academy of Sciences, and the Guggenheim Foundation. We thank Dr. Michael Schechter, Dr. Andrew Bakun, Dr. Francisco P. Chavez, Dr. Tim Pennington, Jose Antonio Mufioz, Ivan Orlic Ticeran, Christine Cass, Marianne Dietz, Dr. Tom Coon, Dr. Roger Calantone, Dr. Carlos Paredes, Dr. Elsa Galarza, Miguel Gallo, Jose Antonio Munoz, Ruben Valdivieso, and Dr. Cesar Torres for important assistance as we prepared the manuscript.

\section{LITERATURE CITED}

Aguero, M., and A. Zuleta. 1994. Management options for transboundary stocks: the Peruvian-Chilean pelagic fishery. Pages 66-78 in E. A. Loayza, editor. Managing fishery resources. World Bank Discussion Paper 217. World Bank, Washington, D. C., USA.

Aguilar Ibarra, A., C. Reid, and A. Thorpe. 2000. The political economy of maritime fisheries development in Peru, Chile and Mexico. Journal of Latin American Studies 32:503-527. http://dx. doi.org/10.1017/S0022216X00005824

Arlinghaus, R., S. J. Cooke, and W. Potts. 2013. Towards resilient recreational fisheries on a global scale through improved understanding of fish and fisher behaviour. Fisheries Management and Ecology 20:91-98. http://dx.doi.org/10.1111/ $\underline{\text { fme. } 12027}$

Avadí, A., P. Fréon, and J. Tam. 2014. Coupled ecosystem/supply chain modelling of fish products from sea to shelf: the Peruvian anchoveta case. Plos One 9:e102057. http://dx.doi.org/10.1371/ journal.pone.0102057

Bakun, A. 2005. Regime shifts. Pages 971-1018 in A. R. Robinson and K. Brink, editors. The sea: volume 13: the global coastal ocean. Harvard University Press, Cambridge, Massachusetts, USA.

Bakun, A., and K. Broad. 2003. Environmental 'loopholes' and fish population dynamics: comparative pattern recognition with particular focus on El Niño effects in the Pacific. Fisheries Oceanography 12:458-473. http://dx.doi.org/10.1046/ j.1365-2419.2003.00258.x
Barber, R. T., and F. P. Chavez. 1983. Biological consequences of El Niño. Science 222:1203-1210. http://dx.doi.org/10.1126/ science. 222.4629 .1203

Berrios, R., and C. Blasier. 1991. Peru and the Soviet Union (1969-1989): distant partners. Journal of Latin American Studies 23:365-384. http://dx.doi.org/10.1017/S0022216X00014036

Basurto, X., S. Gelcich, and E. Ostrom. 2013. The social ecological system framework as a knowledge classificatory system for benthic small-scale fisheries. Global Environmental ChangeHuman and Policy Dimensions 23(6):1366-1380. https://doi. org/10.1016/j.gloenvcha.2013.08.001

Bertrand, A., M. Segura, M. Gutiérrez, and L. Vásquez. 2004. From small-scale habitat to loopholes to decadal cycles: a habitatbased hypothesis explaining fluctuation in pelagic fish populations off Peru. Fish and Fisheries 5:296-316. http://dx.doi. org/10.1111/j.1467-2679.2004.00165.x

Bodin, Ö., and C. Prell. 2011. Social networks and natural resource management: uncovering the social fabric of environmental governance. Cambridge University Press, Cambridge, UK. http:// dx.doi.org/10.1017/CBO9780511894985

Borlaug, N. E. 1973. Civilization's future: a call for international granaries. Bulletin of the Atomic Scientists 29:7-15. http://dx.doi. org/10.1080/00963402.1973.11455509

Botsford, L. W., J. C. Castilla, and C. H. Peterson. 1997. The management of fisheries and marine ecosystems. Science 277:509-515. http://dx.doi.org/10.1126/science.277.5325.509

Cao, L., R. Naylor, P. Henriksson, D. Leadbitter, M. Metian, M. Troell, and W. Zhang. 2015. China's aquaculture and the world's wild fisheries. Science 347:133-135. http://dx.doi.org/10.1126/ science. 1260149

Carlson, A. K., W. W. Taylor, J. Liu, and I. Orlic. 2017. The telecoupling framework: an integrative tool for enhancing fisheries management. Fisheries 42:395-397. https://doi. org/10.1080/03632415.2017.1342491

Castilla, J. C., J. Espinosa, C. Yamashiro, O. Melo, and S. Gelcich. 2016. Telecoupling between catch, farming, and international trade for the gastropods Concholepas concholepas (loco) and Haliotis spp. (abalone). Journal of Shellfish Research 35 (2):499-506. http://dx.doi.org/10.2983/035.035.0223

China Agriculture Press. 2013. China fishery statistical yearbook 2013. Fishery Bureau, Ministry of Agriculture, Beijing, China.

Christensen, V., S. de la Puente, J. Carlos Sueiro, J. Steenbeek, and P. Majluf. 2014. Valuing seafood: the Peruvian fisheries sector. Marine Policy 44:302-311. http://dx.doi.org/10.1016/j.marpol.2013.09.022

Cinner, J. E. 2011. Social-ecological traps in reef fisheries. Global Environmental Change 21:835-839. http://dx.doi.org/10.1016/j. gloenvcha.2011.04.012

Cinner, J. E., C. Huchery, E. S. Darling, A. T. Humphries, N. A. J. Graham, C. C. Hicks, N. Marshall, and T. R. McClanahan. 2013. Evaluating social and ecological vulnerability of coral reef fisheries to climate change. Plos One. http://dx.doi.org/10.1371/ journal.pone.0074321 
Cinner, J. E., T. R. McClanahan, M. A. MacNeil, N. A. J. Graham, T. M. Daw, A. Mukminin, D. A. Feary, A. L. Rabearisoa, A. Wamukota, N. Jiddawi, S. J. Campbell, A. H. Baird, F. A. Januchowski-Hartley, S. Hamed, R. Lahari, T. Morove, and J. Kuange. 2012. Comanagement of coral reef social-ecological systems. Proceedings of the National Academy of Sciences 109 (14):5219-5222. http://dx.doi.org/10.1073/pnas.1121215109

Crona, B. I., T. M. Daw, W. Swartz, A. V. Norström, M. Nyström, M. Thyresson, C. Folke, J. Hentati-Sundberg, H. Österblom, L. Deutsch, and M. Troell. 2016. Masked, diluted and drowned out: how global seafood trade weakens signals from marine ecosystems. Fish and Fisheries 17:1175-1182. http://dx.doi. org/10.1111/faf.12109

Crona, B. I., T. Van Holt, M. Petersson, T. M. Daw, and E. Buchary. 2015. Using social-ecological syndromes to understand impacts of international seafood trade on small-scale fisheries. Global Environmental Change 35:162-175. http://dx.doi. org/10.1016/j.gloenvcha.2015.07.006

Cury, P., A. Bakun, R. J. M. Crawford, A. Jarre, R. A. Quiñones, L. J. Shannon, and H. M. Verheye. 2000. Small pelagics in upwelling systems: patterns of interaction and structural changes in "wasp-waist" ecosystems. ICES Journal of Marine Science 57:603-618. http://dx.doi.org/10.1006/jmsc.2000.0712

Cushman, G. T. 2013. Guano and the opening of the Pacific world: a global ecological history. Cambridge University Press, New York, New York, USA. http://dx.doi.org/10.1017/CBO9781139047470

Defeo, O., M. Castrejón, R. Pérez-Castañeda, J. C. Castilla, N. L. Gutiérrez, T. E. Essington, and C. Folke. 2016. Comanagement in Latin American small-scale shellfisheries: assessment from long-term case studies. Fish and Fisheries 17 (1):176-192. http://dx.doi.org/10.1111/faf.12101

Deines, J. M., X. Liu, and J. Liu. 2016. Telecoupling in urban water systems: an examination of Beijing's imported water supply. Water International 41:251-270. http://dx.doi.org/10.1080/0250$\underline{8060.2015 .1113485}$

Dreher, A., N. Gaston, and P. Martens. 2008. Towards an understanding of the concept of globalization. Pages 5-23 in A. Dreher, N. Gaston, and P. Martens, editors. Measuring globalisation: gauging its consequences. Springer, New York, New York, USA.

Eriksson, H., H. Österblom, B. Crona, M. Troell, N. Andrew, J. Wilen, and C. Folke. 2015. Contagious exploitation of marine resources. Frontiers in Ecology and the Environment 13:435-440. http://dx.doi.org/10.1890/140312

Essington T. E., L. Ciannelli, S. S. Heppell, P. S. Levin, T. R. McClanahan, F. Micheli, É. E. Plagányi, and I. E. van Putten. 2017. Empiricism and modeling for marine fisheries: advancing an interdisciplinary science. Ecosystems 20:237-244. http://dx. doi.org/10.1007/s10021-016-0073-0

Fang, B., Y. Tan, C. Li, Y. Cao, J. Liu, P.-J. Schweizer, H. Shi, B. Zhou, H. Chen, and Z. Hu. 2016. Energy sustainability under the framework of telecoupling. Energy 106:253-259. http://dx.doi. org/10.1016/j.energy.2016.03.055
Folke, C., R. Biggs, A. V. Norstrom, B. Reyers, and J. Rockstrom. 2016. Social-ecological resilience and biosphere-based sustainability science. Ecology and Society 21(3):41. http://dx.doi.org/10.5751/ ES-08748-210341

Food and Agriculture Organization of the United Nations (FAO). 2010. GLOBEFISH - Analysis and information on world fish trade. United Nations, Rome, Italy. [online] URL: http://www.fao.org/ in-action/globefish/market-reports/resource-detail/en/c/337199/

Food and Agriculture Organization of the United Nations (FAO). 2014. The state of world fisheries and aquaculture. United Nations, Rome, Italy. [online] URL: http://www.fao.org/3/a-i3720e.pdf

Fréon, P., J. C. Sueiro, F. Iriarte, O. F. Miro Evar, Y. Landa, J.-F. Mittaine, and M. Bouchon. 2014. Harvesting for food versus feed: a review of Peruvian fisheries in a global context. Reviews in Fish Biology and Fisheries 24:381-398. http://dx.doi.org/10.1007/ s11160-013-9336-4

Fulton, D. C., and I. R. Adelman. 2003. Social science (the human dimension) in fisheries. Fisheries 28:4.

Fulton, E. A., A. D. M. Smith, D. C. Smith, and I. E. van Putten. 2011. Human behaviour: the key source of uncertainty in fisheries management. Fish and Fisheries 12:2-17. http://dx.doi. org/10.1111/j.1467-2979.2010.00371.x

Galdorisi, G. D., and A. G. Kaufman. 2001. Military activities in the exclusive economic zone: preventing uncertainty and defusing conflict. California Western International Law Journal 32:253-302. [online] URL: https://scholarlycommons.law.cwsl. edu/cgi/viewcontent.cgi?referer=https://www.google.com/

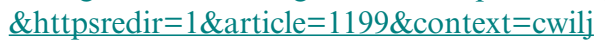

Garcia-Amador, F. V. 1974. The Latin America contribution to the development of the law of the sea. American Journal of International Law 68:33-50. http://dx.doi.org/10.2307/2198801

Gelcich, S., J. Cinner, C. J. Donlan, S. Tapia-Lewin, N. Godoy, and J. C. Castilla. 2017. Fishers' perceptions on the Chilean coastal TURF system after two decades: problems, benefits, and emerging needs. Bulletin of Marine Science 93:53-67. http://dx. doi.org/10.5343/bms.2015.1082

Gephart, J. A., L. Deutsch, M. L. Pace, M. Troell, and D. A. Seekell. 2017. Shocks to fish production: identification, trends, and consequences. Global Environmental Change 42:24-32. http:// dx.doi.org/10.1016/j.gloenvcha.2016.11.003

Gephart, J. A., E. Rovenskaya, U. Dieckmann, M. L. Pace. and Å. Brännström. 2016. Vulnerability to shocks in the global seafood trade network. Environmental Research Letters 11 (3):035008. http://dx.doi.org/10.1088/1748-9326/11/3/035008

Glantz, M. H. 1979. Science, politics and economics of the Peruvian anchoveta fishery. Marine Policy 3:201-210. http://dx. doi.org/10.1016/0308-597X(79)90052-6

Gréboval, D., and G. Munro. 1999. Overcapitalization and excess capacity in world fisheries: underlying economics and methods of control. Food and Agricultural Organization of the United Nations (FAO) Fisheries Technical Paper No. 386. FAO, Rome, Italy. [online] URL: http://www.fao.org/docrep/003/X2250E/ $\underline{\mathrm{x} 2250 \mathrm{e} 03 . \mathrm{htm}}$ 
Hulina, J., C. Bocetti, H. Campa, III, V. Hull, W. Yang, and J. Liu. 2017. Telecoupling framework for research on migratory species in the Anthropocene. Elementa: Science of the Anthropocene 5:5. http://dx.doi.org/10.1525/elementa.184

Hunt, L. M., E. P. Fenichel, D. C. Fulton, R. Mendelsohn, J. W. Smith, T. D. Tunney, A. J. Lynch, C. P. Paukert, and J. E. Whitney. 2016. Identifying alternate pathways for climate change to impact inland recreational fishers. Fisheries 41:362-372. http://dx.doi. org/10.1080/03632415.2016.1187015

Hunt, L. M., S. G. Sutton, and R. Arlinghaus. 2013. Illustrating the critical role of human dimensions research for understanding and managing recreational fisheries within a social-ecological system framework. Fisheries Management and Ecology 20:111-124. http://dx.doi.org/10.1111/j.1365-2400.2012.00870.x

International Fishmeal and Fish Oil Organization (IFFO). 2009. The production of fishmeal and fish oil from Peruvian anchovy. Technical Report No. 2. International Fishmeal and Fish Oil Organization, London, UK. [online] URL: http://www.iffo.net/ system/files/67 0.pdf

Instituto del Mar del Peru (IMARPE). 1970. Panel of experts' report on the economic effects of alternative regulatory measures in the Peruvian anchoveta fishery. Reprinted on pages 369-400 in M. H. Glantz and J. D. Thompson, editors. Resource management and environmental uncertainty: lessons from coastal upwelling fisheries. 1983. John Wiley and Sons, New York, New York, USA.

Knuth, B. A. 2002. The many faces of salmon: implications of stakeholder diversity in the Great Lakes. Pages 181-192 in K. D. Lynch, M. L. Jones, and W. W. Taylor, editors. Sustaining North American salmon: perspectives across regions and disciplines. American Fisheries Society, Bethesda, Maryland, USA.

Lemay, M. H. 1998. Coastal and marine resources in Latin America and the Caribbean. Inter-American Development Bank. Washington, D.C., USA. [online] URL: https://publications.iadb. org/handle/11319/4757

Liu, J., T. Dietz, S. R. Carpenter, C. Folke, M. Alberti, C. L. Redman, S. H. Schneider, E. Ostrom, A. N. Pell, J. Lubchenco, W. W. Taylor, Z. Ouyang, P. Deadman, T. Kratz, and W. Provencher. 2007a. Coupled human and natural systems. Ambio 36:639-649. http://dx.doi.org/10.1579/0044-7447(2007)36[639:CHANS] 2.0. $\mathrm{CO} ; 2$

Liu, J., T. Dietz, S. R. Carpenter, M. Alberti, C. Folke, E. Moran, A. N. Pell, P. Deadman, T. Kratz, J. Lubchenco, E. Ostrom, Z. Ouyang, W. Provencher, C. L. Redman, S. H. Schneider, and W. W. Taylor. 2007b. Complexity of coupled human and natural systems. Science 317:1513-1516. http://dx.doi.org/10.1126/ science. 1144004

Liu, J. G., V. Hull, M. Batistella, R. DeFries, T. Dietz, F. Fu, T. W. Hertel, R. C. Izaurralde, E. F. Lambin, S. Li, L. A. Martinelli, W. J. McConnell, E. F. Moran, R. Naylor, Z. Ouyang, K. R. Polenske, A. Reenberg, G. de Miranda Rocha, C. S. Simmons, P. H. Verburg, P. M. Vitousek, F. Zhang, and C. Zhu. 2013. Framing sustainability in a telecoupled world. Ecology and Society 18 (2):26. http://dx.doi.org/10.5751/ES-05873-180226

Liu, J., V. Hull, J. Luo, W. Yang, W. Liu, A. Viña, C. Vogt, Z. Xu, H. Yang, J. Zhang, L. An, X. Chen, S. Li, Z. Ouyang, W. Xu, and
H. Zhang. 2015. Multiple telecouplings and their complex interrelationships. Ecology and Society 20(3):44. http://dx.doi. org/10.5751/ES-07868-200344

Liu, J., V. Hull, W. Yang, A. Viña, X. Chen, Z. Ouyang, and H. Zhang, editors. 2016. Pandas and people: coupling human and natural systems for sustainability. Oxford University Press, Oxford, UK.

Liu, J., W. Yang, and S. Li. 2016. Framing ecosystem services in the telecoupled Anthropocene. Frontiers in Ecology and the Environment 14:27-36. http://dx.doi.org/10.1002/16-0188.1

McPhaden, M. J. 2003. El Niño and La Niña: causes and global consequences. Pages 353-370 in R. E. Munn, M. C. MacCracken, and J. Perry, editors. Encyclopedia of global environmental change. John Wiley and Sons, Hoboken, New Jersey, USA.

Mondoux, S., T. Pitcher, and D. Pauly. 2008. Ranking maritime countries by the sustainability of their fisheries. Pages 13-27 in J. Alder and D. Pauly, editors. A comparative assessment of biodiversity, fisheries, and aquaculture in 53 countries' exclusive economic zones. Fisheries Centre, University of British Columbia, Vancouver, British Columbia, Canada. [online] URL: http:// www.seaaroundus.org/doc/publications/books-and-reports/2008/ Alder-and-Pauly-comparative-assessment-of-biodiversity-fisheriesand-aquaculture-53-countries-EEZ.pdf

Norton, J. G., and J. E. Mason. 2005. Relationship of California sardine (Sardinops sagax) abundance to climate-scale ecological changes in the California Current system. CalCOFI Report 46:83-92. [online] URL: http://calcofi.org/publications/calcofireports/ v46/Vol 46 Norton Mason Environmental Influences.pdf

Orlic, I. 2011. Innovation, leadership, and management of the Peruvian anchoveta fishery: approaching sustainability. Pages 145-183 in W. W. Taylor, A. J. Lynch, and M. G. Schechter, editors. Sustainable fisheries: multi-level approaches to a global problem. American Fisheries Society, Bethesda, Maryland, USA.

Österblom, H., and C. Folke. 2015. Globalization, marine regime shifts and the Soviet Union. Philosophical Transactions of the Royal Society B. 370: 20130278. http://dx.doi.org/10.1098/ rstb. 2013.0278

Paulik, G. J. 1981. Anchovies, birds, and fishermen in the Peru Current. Pages 35-80 in M. H. Glantz and J. D. Thompson, editors. Resource management and environmental uncertainty: lessons from coastal upwelling fisheries. John Wiley and Sons, New York, New York, USA.

Pinsky, M. L., and M. Fogarty. 2012. Lagged social-ecological responses to climate and range shifts in fisheries. Climate Change Letters 115:883-891. http://dx.doi.org/10.1007/s10584-012-0599$\underline{x}$

Roemer, M. 1970. Fishing for growth: export-led development in Peru, 1950-1967. Harvard University Press. Cambridge, Massachusetts, USA. http://dx.doi.org/10.4159/harvard.9780674418417

Smith, M. D., C. A. Roheim, L. B. Crowder, B. S. Halpern, M. Turnipseed, J. L. Anderson, F. Asche, L. Bourillón, A. G. Guttormsen, A. Khan, L. A. Liguori, A. McNevin, M. I. O'Connor, D. Squires, P. Tyedmers, C. Brownstein, K. Carden, D. H. Klinger, R. Sagarin, and K. A. Selko. 2010. Sustainability 
and global seafood. Science 327:784-786. http://dx.doi. org/10.1126/science. 1185345

Sun, J., Y.-X. Tong, and J. Liu. 2017. Telecoupled land-use changes in distant countries. Journal of Integrative Agriculture 16:368-376. http://dx.doi.org/10.1016/S2095-3119(16)61528-9

Tapia-Lewin, S., K. Vergara, C. De La Barra, N. Godoy, J. C. Castilla, and S. Gelcich. 2017. Distal impacts of aquarium trade: exploring the emerging sandhopper (Orchestoidea tuberculata) artisanal shore gathering fishery in Chile. Ambio 46:706-716. http://dx.doi.org/10.1007/s13280-017-0906-x

Taylor, W. W., N. J. Leonard, J. F. Kratzer, C. Goddard, and P. Stewart. 2007. Globalization: implications for fish, fisheries, and their management. Pages 21-46 in W. W. Taylor, M. S. Schechter, and L. G. Wolfson, editors. Globalization: effects of fisheries resources. Cambridge University Press, New York, New York, USA. http://dx.doi.org/10.1017/CBO9780511542183.005

von der Heyden, S., M. Beger, R. J. Toonen, L. van Herwerden, M. A. Juinio-Meñez, R. Ravago-Gotanco, C. Fauvelot, and G. Bernardi. 2014. The application of genetics to marine management and conservation: examples from the Indo-Pacific. Bulletin of Marine Science 1:123-158. http://dx.doi.org/10.5343/ bms.2012.1079

Watson, R. A., B. S. Green, S. R. Tracey, A. Farmery, and T. J. Pitcher. 2016. Provenance of global seafood. Fish and Fisheries 17:585-595. http://dx.doi.org/10.1111/faf.12129

Wilson, J. A. 2006. Matching social and ecological systems in complex ocean fisheries. Ecology and Society 11(1):9. http://dx. doi.org/10.5751/ES-01628-110109

Yang, D., J. Cai, V. Hull, K. Wang, Y.-P. Tsang, and J. Liu. 2016. New road for telecoupling global prosperity and ecological sustainability. Ecosystem Health and Sustainability 2:10. http:// dx.doi.org/10.1002/ehs2.1242

Yang, W., D. W. Hyndman, J. A. Winkler, A. Viña, J. M. Deines, F. Lupi, L. Luo, Y. Li, B. Basso, C. Zheng, D. Ma, S. Li, X. Liu, H. Zheng, G. Cao, Q. Meng, Z. Ouyang, and J. Liu. 2016. Urban water sustainability: framework and application. Ecology and Society 21(4):4. http://dx.doi.org/10.5751/ES-08685-210404 